\title{
Study on the effect of aqueous leaf extract of Anacardium occidentale on seed germination and seedling growth of Vigna unguiculata.
}

\author{
Sheeja P Parayil ${ }^{1}$, Honey ${ }^{2}$ and Abhilash ES ${ }^{1}$
}

${ }^{1}$ Assistant Professor, P.G. Department of Botany, Sree Narayana College, Nattika, Thrissur, Kerala.

${ }^{2}$ PG Student, P.G. Department of Botany, Sree Narayana College, Nattika, Thrissur, Kerala.

\section{Original Article}

\section{Corresponding Author}

Sheeja P Parayil

Assistant Professor, P.G. Department of Botany

Sree Narayana College

Nattika, Thrissur, India

Email:shjpparayil@gmail.com

\section{Abstract \\ Allelochemicals play a significant role in the germination and seedling growth of crop plants. Various allelochemicals are present in Anacardium. These chemicals enter into the crops environment and adversely affect the growth of crop and reduce their yield. It is seen that with increase in the concentration of leaf extract there is a decrease in germination value, germination percentage, cumulative germination percentage, shoot length, root length, leaf area, fresh weight, dry weight and stomatal index. For the successful cultivation of cowpea, the seeds should be grown away from this plant.}

Key Words: Allelopathy, cumulative germination percentage, leaf area, Anacardium, stomatal index.

\section{Introduction}

Every organism has its own specific environment to which it continuously interact and adapted. The living environment includes all living things both plants and animals and their direct or indirect interactions. Various types of interactions occur among plants. These interactions may either beneficial to the participants or harmful. In some cases one population inhibit the growth and development of other population by the release of an effective phytotoxin into the environment. This is called 'Allelopathy'.

The term allelopathy derives from two separate Greek words. They are allelon which means "of each other" and pathos which means "to suffer". Allelopathy is characteristic of certain plants, algae, bacteria, coral and fungi. Bio-chemicals that produced by them are known as 'allelochemicals' wich influence the growth, survival and reproduction of other organisms.

It can have beneficial (positive allelopathy) or detrimental (negative allelopathy) effects on the target organisms. Allelochemicals are the subsets of secondary metabolities (Stamp Nancy, 2003). It includes terpenoids, phenolic compounds, alkaloids, fatty acids, steroids and polyacetylenes (Kohli, 1998). Allelopathic substances present in any part of the plant i.e. leaves, roots, fruits, stems, rhizomes and seeds from where they are released to the soil through four biochemical process such as weathering, leaching, exudation and volatilization. The present work was conducted to study the effect of aqueous leaf extract of Anacardium occidentale on seed germination and seedling growth of Vigna unguiculata.

\section{Material and Methods}

\section{Anacardium occidentale $L$.}

$\begin{array}{ll}\text { Family } & \text { : Anacardiaceae } \\ \text { Common name } & \text { : Cashew }\end{array}$

Anacardium is a spreading, evergreen, perennial tree; it is native to Brazil and is planted throughout the tropical regions of the world where it is a very important economic crop for some countries.

\section{Vigna unguiculata ( L). Walp}

$\begin{array}{ll}\text { Family } & : \text { Fabaceae (Leguminosae) } \\ \text { Sub-family } & : \text { Papilionaceae } \\ \text { Common name } & : \text { Cowpea }\end{array}$

Cowpeas are well adapted to the drier regions of the tropics, where other food legumes do not perform well. It is an erect, semi erect, prostrate herb.

The Vigna unguiculata seeds, Lola (VS $13-2$ ) variety are 
used for this particular study. The seeds were brought from Agricultural University Mannuthy. It is very common, high yield, extra long, light green pods with purple tip. Its average pod length is $38-53 \mathrm{~cm}$ and average pod weight $22 \mathrm{~g}$.

The seeds were cleaned by washing in running tap water. Then surface sterilized with $0.1 \% \mathrm{HgCl}_{2}$ solution for 3 to 4 minutes and thoroughly washed in distilled water and dried on filter paper to eliminate fungal attack.

Leaves of Anacardium occidentale collected from the field and washed in running tap water. Then surface sterilized with $0.1 \% \mathrm{HgCl}_{2}$ solution for $3-4$ minutes and thoroughly washed in distilled water. Then these leaves were crushed and grinded separately for extraction. These leaf extracts were filtered through a Whatman No. 1 filter paper and stored in refrigerator. The pure aqueous extract obtained was taken as a stock solution (100\%) and further diluted to various concentrations, such as $25 \%, 50 \%$ and $75 \%$ by adding distilled water. In a control set, seeds are treated in distilled water.

The petridishes were sterilized in an autoclave at $120^{\circ} \mathrm{C}$. Sterilized seeds were then arranged equidistantly over Whatman No. 1 filter paper in petridishes. Each petridish contain 25 seeds. The seeds were moistened with requisite amount of extract solution. Three replicates were always maintained. The petridishes were kept at room temperature $\left(28-30^{\circ} \mathrm{c}\right)$.

After two days, the germination was observed. Radical emergence was considered as the criteria for seed germination. Germination count in each treatment was recorded. Five germinated seeds from each concentration were then transferred to separate polythene bags filled with potting mixture. Above mentioned concentration of extract were used for treatment. Control seedlings were treated with distilled water. The plants were well protected and kept for 10 days of observation. After 10 days of treatment, five plants were collected then shoot length, root length, leaf area, fresh weight and dry weight were studied and compared with control.

Then other plants were grown under above mentioned conditions and kept for 30 days of observation. After 30 days plants were collected then again shoot length, root length, leaf area, fresh weight, stomatal index is measured and compared with control. Parameters selected for this study are:-

\section{GERMINATION STUDIES}

a. Germination value

b. Germination percentage

c. Cumulative germination percentage

\section{MORPHOLOGICAL STUDIES}

a. Length of shoot
b. Length of root
c. Leaf area
d. Fresh weight and dry weight

\section{STOMATAL INDEX}

\section{CORRELATION STUDY}

\section{Germination parameters}

\section{Germination value (G.V)}

Germination value is the average germination of seeds.

\section{Germination percentage (G.P)}

Germination percentage (G.P) $=$

No. of seeds germinated $\times 100$

Total no. of seeds used

\section{Cumulative germination percentage (C.G.P)}

C.G.P $=$ Germination value $\times 100$

Total no. of seeds used

\section{Morphological parameters}

\section{a. Length of shoot and length of root}

After 10 days of treatment in the polythene bags, the plant were picked up and length of shoot and root was taken. It was measured in centimeters using a thread and scale. Then after 30 days this was repeated again.

\section{b. Leaf area}

Leaf area is calculated by taking the mean value of length of basal, middle and tip region of leaf. It is also measured after 30 days.

\section{c. Fresh weight and dry weight}

After 10 days of observation in polythene bags, plants were collected and fresh weight was taken. The plants were then dried in hot air oven at room temperature $\left(35-37^{\circ} \mathrm{c}\right)$ until a constant weight is obtained, and dry weight was taken.

\section{STOMATAL INDEX}

Stomatal index was calculated by the following formula Stomatal index $=$ Number of stomata Number of stomata + epidermal cells

IV. CORRELATION ANALYSIS 
Results:

The seeds of Vigna unguiculata were treated with different concentrations (25, 50, 75 and $100 \%)$ of Anacardium occidentale leaf extract.

\section{GERMINATION STUDIES}

\section{a. Germination Value (G.V.)}

In the case of seeds treated with leaf extract of Anacardium, the G.V. is $20.66,17,16$ and 10.33 at 25, 50, 75 and $100 \%$ concentrations respectively.

In control, germination value is 23.66 .

\section{b. Germination Percentage (G.P.)}

In the case of seeds treated with leaf extract of Anacardium, the G.P. is $82.67,68,64$ and 68,64 and 41.33 . In control G.P. is 94.66. (Table 1)

\section{Table-1. Germination Studies}

\begin{tabular}{|l|c|c|c|c|}
\hline Concentration & CONTROL & $25 \%$ & $50 \%$ & $75 \%$ \\
\hline $\begin{array}{l}\text { GERMINATION } \\
\text { VALUE }\end{array}$ & 23.66 & 20.66 & 17.00 & 33.00 \\
$\begin{array}{l}\text { GERMINATION } \\
\text { PERCENTAGE }\end{array}$ & 94.66 & 82.67 & 68.00 & 64.00 \\
CGP & 31.54 & 27.55 & 22.67 & 21.33 \\
\hline
\end{tabular}

c. Cumulative Germination Percentage (C.G.P.)

In the case of seeds treated with leaf extract of Anacardium, C.G.P. is in the order 27.55, 22.67, 21.33 and 13.77 at $25,50,75$ and $100 \%$ concentrations respectively. In control CGP is 31.54 .

\section{MORPHOLOGICAL STUDIES}

\section{a. Shoot Length}

In the case of seeds treated with leaf extract of Anacardium shoot length is 12.66 and $9.1 \mathrm{~cm}$ at 25 and $50 \%$ concentrations respectively. In the case of 75 and $100 \%$, seedlings do not survive. In the case of control shoot length is $19.6 \mathrm{c} . \mathrm{m}$.After 30 days plant showed shoot length of $22.3 \mathrm{~cm}$ at $25 \%$ concentration. Plants in the $50 \%$ concentration did not survive. In control, shoot length was $25 \mathrm{c} . \mathrm{m}$.(Table - 2)

Table-2. Morphological Studies

\begin{tabular}{|l|c|c|c|c|}
\hline & CONTROL & $25 \%$ & $50 \%$ & $75 \%$ \\
\hline Shoot length $(\mathrm{cm})$ & 19.6 & 12.66 & 9.1 & - \\
\hline Root length $(\mathrm{cm})$ & 6.26 & 3.46 & 1.46 & - \\
\hline Leaf area $(\mathrm{cm})$ & 5.82 & 4.2 & 3.84 & - \\
\hline Fresh wt (g) & 0.92 & 0.85 & 0.76 & - \\
\hline Dry wt (g) & 0.11 & 0.08 & 0.06 & - \\
\hline Stomatal index & 0.317 & 0.293 & - & - \\
\hline
\end{tabular}

\section{b. Root Length}

In the case of seeds treated with leaf extract of Anacardium have root length in the pattern of 3.46 and $1.46 \mathrm{~cm}$ at 25 and $50 \%$ respectively. In control root length is $6.26 \mathrm{~cm}$.After 30 days root length was of $4 \mathrm{~cm}$ at $25 \%$ concentration. The plant in $50 \%$ did not survive.Control showed root length $7 \mathrm{~cm}$.

\section{c. Leaf Area}

In the case of leaf area of the plants treated with Anacardium shows 4.2 and $3.84 \mathrm{~cm}$ at 25 and $50 \%$ concentrations. In control, leaf area is $5.82 \mathrm{~cm}$. After 30 days leaf area is $6 \mathrm{~cm}$ at $25 \%$ concentration. In control, leaf area is $6.12 \mathrm{~cm}$.

\section{d. Fresh Weight and Dry Weight}

In the case of plants treated with leaf extract of Anacardium, fresh weight was in the pattern of 0.85 and $0.76 \mathrm{~g}$ at 25 and $50 \%$ concentrations. The dry weight was 0.08 and 0.06 g at 25 and $50 \%$ respectively. Control plants showed the fresh weight $0.92 \mathrm{~g}$. The dry weight was $0.11 \mathrm{~g}$.

\section{STOMATAL INDEX}

In the case of seed treated with leaf extract of Anacardium, stomatal index was 0.293 at $25 \%$ concentration. Control plants showed the stomatal index 0.317

\section{CORRELATION ANALYSIS}

Correlation coefficient of Anacardium occidentale was 0.9658 .

\section{Discussion:}

Germination value, Germination percentage and Cumulative germination percentage also decreased with increasing concentration of the Anacardium leaf extract. The inhibition was directly proportional to extract concentration. Muhammad Kamal Hossain and Md. Nazmul Alam (2010) observed similar results in Lantana camara leaf extract. Inhibitory effect was proportional to the concentration of the extract. Higher concentration had strong inhibitory effect and lower concentration showed stimulatory effect.

Reduction in germination also reported by Izzet Kadioglu and Yusuf Yanar (2004). They studied the effect of twenty two plant's extracts on germination of seeds from nine different weeds. Result showed that some seeds are slightly affected, some stimulated the seed germination by the extract treatments. Many seeds inhibit the germination in all the plant extract. Hassan S. Al-Zahrani and samy A. Al-Robai (2007) reported that germination delayed at higher concentration and germination percentage was decreased by increasing leaf extract of Calotropis procera in some plants like Barley, Wheat, Cucumber, Fenugreek and Alssana.

The statistical study between concentrations of plant extract and C.G.P showed negative correlation. The correlation coefficient value was negative. 
V)raPJEESD

Study on the effect of aqueous leaf extract of Anacardium occidentale on seed germination and seedling growth of

After the germination, the seedlings were transferred to separate polythene bags and the experiment continued for 10 days. After 10 days the shoot length, root length, leaf area, fresh weight, dry weight and stomatal index were studied and compared with control.

Maximum inhibition in shoot and root length occur at higher concentration. In $75 \%$ and $100 \%$ concentrations the seedling growth did not take place. Studies of allelopathic potential of fresh and dry leaves of Eucalyptus citriodora on amaryllis and grassy weeds by EI - Rokiek and Eid (2009) showed that maximum inhibition in shoot and root length of wild oat reported at the higher concentration of the aqueous extract.

Reduction in shoot and root length reported by EI - Darier (2002). He observed that Eucalyptus leaf litter water extract reduce the shoot and root length of Broad bean than in Maize. Alsaadawi and Salih (2009) reported that root exudates of Cyperus rotundus reduced the root and shoot growth of Tomato and Cucumber plants.

Anacardium leaf extract also reduce fresh and dry weight at higher concentration. The seedlings occured only in the $25 \%$ concentration. Other concentration like $75 \%$ and $100 \%$ seedling did not survive. Oyun (2006) studied the allelopathic potentialities of Gliricidia sepium and Acacia auriculiformis on germination and seedling vigour of Maize. The result showed that shoot fresh weight and root dry weight decreased with increasing concentration of the extract.

In the case of Anacardium leaf extract, the seedlings did not survive at high concentrations (50\%, 75\% and $100 \%)$. Only seedlings survive at $25 \%$ concentration of leaf extract. Seedlings in $25 \%$ concentration also show lower values than control. Here thus the experimental results were also agreed with previous allelopathic works.

The present study showed that leaves of Anacardium occidentale exhibit a negative effect on germination and growth of crop plant Vigna unguiculata. The leaf extract have inhibitory effect. At higher concentrations (75\% and 100\%) Anacardium occidentale leaf extract inhibit seedling growth. Thus allelo-chemicals present inhibit the growth of neighboring crops and reduce their yield.

\section{Conclusion:}

Allelopathy is the phenomenon in which one plant releases chemicals which could either stimulate or inhibit the growth of others in the vicinity. Allelochemicals are produced by plants as end products, by-products and metabolites. These are present in the leaves, stem, roots, flowers, inflorescence, fruits and seeds of the plant. Among all these plant parts, leaves are the most consistent producer of these allelochemicals.

From the present study conducted, it is obvious that at lower concentration of leaf extract there is a high percentage of germination and growth of seedling. With increase in the concentration of leaf extract, percentage of germination decreases and growth of seedlings did not take place.

From all the observations, it can be concluded that with increase in the concentration of leaf extract there is a decrease in germination value, germination percentage, cumulative germination percentage, shoot length, root length, leaf area, fresh weight, dry weight and stomatal index.

From the above results we can conclude that allelochemicals play a significant role in the germination and seedling growth of crop plants. Various allelochemicals are present in Anacardium. These chemicals enter into the crops environment and adversely affect the growth of crop and reduce their yield. For the successful cultivation of cowpea, the seeds should be grown away from this plant.

\section{Acknowledgments:}

The authors are thankful to Principal, S.N.College, Nattika, Dr. A.R.Raju, H.O.D. Botany for their valuable support during the study.

\section{References:}

Alsaadawi, I.S . and Salih, N.M.M. 2009. Allelopathic potential of Cyperus rotundus L. interference with crops. Allelopathy Journal. 23(2): 11-17.

El- Darier, S.M.2002. Allelopathic effects of Eucalyptus rostrata on growth, nutrient uptake and metabolic accumulation of Vicia faba $L$ and Zea mays L. Pak. Jour. Biol. Sci.(5):6-11.

El- Rokiek,K.G and Eid, R.A. 2009. Allelopathic effect of Eucalyptus ctiriodora on amaryllis and associated grassy weed. Planta daninha. 27: 83-90.

Hassan S. Al-Zahrani and Samy A. Al-Robai.2007. Allelopathic Effect of Calotropis procera Leaves Extract on Seed Germination of Some Plants. Journal of King Abdulaziz University , Science Journal , 19 (1):115-126.

Izzet Kadioglu and Yusuf Yanar.2004. Allelopathic effect of plant extract against seed germination of some weeds. Asian. J. Plant. Science.3 (4): 472-475

Kohli,R.K; Batish, D and Singh,H.P. 1998. Allelopathy and its implications in agroecosystems. J.Crop.Prod.1 : 169-202.

Muhammad Kamal Hossain and M.D Nazmul Alam. 2010. Allelopathic effect of Lantana camara leaf extract on germination and growth behaviour of some agricultural and forest crops in Bangladesh. Pak. J.weed sci. Res. 16 (2): $217-$ 226.

Oyun, M.B. 2006. Potentiality of Gliricidia sepium and Acacia auriculiformis on the germination and seeding vigour of 
Zea mays L. American Journal of Agricultural and Biological science. 1 (3) : 44-47.

Stamp Nancy. 2003. Out of the quagmire of plant defense hypothesis. The Quarterly Review of Biology. 78 (1): 23-55.

\begin{tabular}{|l|l|}
\hline \multicolumn{2}{|c|}{ Article Information } \\
\hline \multicolumn{2}{|c|}{ Article history } \\
\hline Received & 11 October 2012 \\
Received in revised form & 29 November 2012 \\
Accepted & 2 December 2012 \\
\hline
\end{tabular}

